\title{
OVIPIN
}

1

Article

\section{Ovipin: a chicken eggs antibiotic agent}

\author{
Sandra Regina dos SANTOS ${ }^{1,2,3, ;}$; Antonio MIRANDA ${ }^{1,2}$; Pedro Ismael da SILVA JUNIOR ${ }^{1,3,}$ \\ ${ }^{1}$ Biological Sciences (Molecular Biology) Post-Graduation Program - UNIFESP \\ 2 Department of Biophysics, UNIFESP, São Paulo CEP 04023-062, Brazil; amiranda@unifesp.br \\ ${ }^{3}$ Laboratory for Applied Toxin ology - Center of Toxins, Immune-Response and Cell Signaling \\ - CeTICS/CEPID, Butantan Institute, São Paulo CEP 05503-900, SP, Brazil \\ *Correspondence: sandrasantos111@gmail.com; Tel.: +55-15-98167-9581; \\ pisjr@butantan.gov.br; Tel.:+55-11-2627-9731
}

\begin{abstract}
The intensive and indiscriminate use of antibiotic has increased cases of microorganisms resistance and becoming a worldwide public health problem. In the last years, from natural sources such as hen's egg, have received special attention in the discovery of new bioactive compounds. This study aims to identify and characterize a new peptide from chicken egg of Gallus gallus domesticus. The peptide was isolated and purified by high-performance liquid chromatography (HPLC), and its antimicrobial activity was evaluated through liquid growth inhibition assays. The peptide, Ovipin, presented antimicrobial activity against Gram-positive bacteria, Filamentous fungus and Yeast, not cause significant hemolytic effect against human erythrocytes. The molecular weight and amino acid sequence of the peptide was determined by mass spectrometry (MS). Ovipin primary sequence is YVSPVAIVKGLNIPL and a molecular weight of $1,581.94 \mathrm{Da}$. Ovipin shows $100 \%$ and $93.3 \%$, respectively, sequence similarity with the fragments Apolipoprotein B of Gallus gallus and Apolipoprotein B of five others species of Aves. Our data suggest that Ovipin peptide could be a potential therapeutic candidate to be used in combination with other antimicrobial molecules or an alternative led compound for substitution the conventional antibiotics against infections developed by resistant microorganisms.
\end{abstract}

Keywords: 1: Ovipin; 2: chicken eggs; 3: antimicrobial; 4: peptide; 5: AMPs.

\section{Introduction}

Antibiotics are natural or synthetic compounds that can inhibit the growth or to induce microorganisms (bacteria or fungus) death (Guimarães et al., 2010), but the increase in cases of infection triggered by resistant microorganisms is difficult to treat with conventional antibiotics available. The antibiotic resistance problem has motived the search for new molecules for infection control such as finding novel non-traditional antibiotic sources or elaborating combinations between commercial available antibiotics to generate synergistic effects (Garcia et al., 2013).

In this regard, antimicrobial peptides (AMPs) are evolutionarily conserved innate immune defense system and are produced by many organisms (Peters et al., 2010), such as Prokaryotes 
(e.g., bacteria) and Eukaryotes (e.g., protozoan, fungi, plants, insects and animals) (Izadpanah \& Gallo, 2005; Bahar \& Ren, 2013). These molecules play an important role, as they act as a firstline defense system and can be constitutively present or induced through external stimuli (Mookherjee \& Hancock, 2007), They are widely studied by presenting a fast and broad spectrum of action against Gram-positive and Gram-negative bacteria, fungi, protozoa and viruses and act as a cytotoxic component against some types of cancers (Kang et al., 2014; Andreu \& Rivas, 1998; Cruz et al., 2014). Thus presenting the ability to inhibit growth or kill multi-resistant microorganism (Peters et al., 2010).

Antimicrobial peptides (AMPs) are small (weight $<10 \mathrm{kDa}$ ) an in general amphipathic molecules, positively or negatively charged with amino acids sequences diversity (five to 100 amino acids), (Bahar \& Ren, 2013; Cruz et al., 2014). They are selective for prokaryotic membranes and act on the cell membrane-disruptive of microorganisms through electrostatic interactions and show low natural resistance. The positive charges present on the peptide chains favor an electrostatic interaction with the negative charges of the phospholipids present on the surface of the microorganism's membranes (Zasloff, 2002). This electrostatic followed by an hydrophobic interactions causes an increase in the permeability of the membrane and leading to a spillage of the internal content of the microorganism (Shai, 1999). Some peptides have no action on the cell membrane, but rather they cross this membrane and act on intracellular targets, which can interfere in crucial processes for the growth and development of microorganisms. Thus, these AMPs can inhibit cell wall formation, block nucleic acid synthesis processes, prevent protein synthesis or inhibit some enzyme activity (Brogden, 2005).

On the other hand, in the last years has also growth the interest in the search for bioactive molecules in food sources. The functional foods contain amounts and types of bioactive compounds different, which provide health benefits and may decrease the development of chronic diseases (Gil-Chávez et al., 2013; Rutherfurd-Markwick, 2012). As a natural source, the chicken eggs with their diversity of structure and variety of components are increasingly becoming targets of research in health or biotechnology (Hancock \& Sahl, 2006). Chicken eggs is an important dietary source because it is rich in proteins, lipids, vitamins and minerals, but which are associated with other functions such as defense to inhibit the invasion and proliferation of pathogens (Kovacs-Nolan et al., 2005). As example, the Lysozyme is one of the main proteins of the egg is that it has a potent antimicrobial action. This protein has bactericidal activity against Gram-positive bacteria, breaking the beta 1-4 bond between $\mathrm{N}$-acetylmuramic acid and $\mathrm{N}$-acetylglucosamine 
acid of the cell wall resulting in the inhibition and death of this microorganism (Ercan and Demirci, 2016).

Then, the discovery of new AMPs from natural sources is of great importance for public health, since these molecules are pharmacological candidates due to their effective antimicrobial activity and low resistance rates (Peters et al., 2010). The aim of this work is to performed the bioprospecting on chicken eggs of specie Gallus gallus domesticus, with focus in the discovery of new antimicrobial peptides with great potential to act against microorganisms, especially microorganisms that have already developed some resistance mechanism.

\section{Materials and Methods}

\section{Chicken Extract preparation}

In this study chicken eggs without the shell of the species Gallus gallus domesticus were utilized. They were purchased from the commercial market network in the city of São Paulo/SP.

The total chicken eggs crude were submitted to acid extraction in the presence of Acetic Acid 2 mol.L-1 , with constant agitation for $60 \mathrm{~min}$ at $4^{\circ} \mathrm{C}$. After the stirring time, the insoluble material was separated by centrifugation at $3113 \times \mathrm{g}$ for $30 \mathrm{~min}$ and the supernatant obtained was injected into coupled Sep-Pack ${ }_{18}$ cartridges (Waters Associates - $20 \mathrm{cc}$ vac cartridge, $5 \mathrm{~g}$, and particle weight 55-105 $\mu \mathrm{m})$ equilibrated in trifluoroacetic acid $(0,1 \%$ TFA). The supernatant was pre-fractionated in three different acetonitrile $(\mathrm{ACN})$ concentrations $(5 \%, 40 \%$, and $80 \%$ of $\mathrm{ACN})$, using vacuum manifold system equipment (SPE 12 positions aho 6023 - Phenomenex) and then were lyophilized.

\section{Fractionation of Antimicrobial Peptides}

The fractions, $5 \%, 40 \%$ and $80 \%$ of $\mathrm{ACN}$ with $2 \mathrm{~g}$ each, were reconstituted in $5 \mathrm{~mL} 0.1 \%$ TFA and subjected by reverse-phase high-performance liquid chromatography (RP-HPLC) was carried out at room temperature on a Shimadzu LC-8A system. The column was a Shim-Pack Preparative ODS C-18 (20 mm x $250 \mathrm{~mm}$; particle weight $10 \mu \mathrm{m}$; pore weight $300 \AA)$. The elution was performed with a linear ACN gradient, equilibrated in $0.1 \%$ TFA for $60 \mathrm{~min}$ at a flow rate of 8.0 $\mathrm{mL} / \mathrm{min}(0$ to $20 \%$ ) for the fraction eluted in $5 \%, 2$ to $60 \%$ for the fraction in $40 \%$, and 20 to $80 \%$ fraction eluted in $80 \%$. The ultraviolet (UV) absorbance of the effluent was monitored at $225 \mathrm{~nm}$. 
The fractions were manually collected, were vacuum-dried and suspended in $1 \mathrm{~mL}$ in ultrapure water for antimicrobial activity assays. No fractions with antimicrobial activity were identified in the samples eluted in $5 \%, 40 \%$ of ACN.

The molecule described in this work, fraction 21, was subjected to a second step of fractionation using linear gradient of ACN (39 to 49\%) with 0,05\% TFA at a flow rate of $2 \mathrm{~mL} / \mathrm{min}$ for $60 \mathrm{~min}$ on the same column Shim-Pack Preparative ODS C-18 $(20 \mathrm{~mm} \times 250 \mathrm{~mm}$; particle weight $10 \mu \mathrm{m}$; pore weight $300 \AA$ ). The fractions were hand-collected, were vacuum-dried, suspended in $500 \mu \mathrm{L}$ in ultrapure water and it was quantified based on absorbance $205 \mathrm{~nm}$ using a NanoDrop 2000 spectrophotometer (Thermo Fischer Scientific, Waltham, MA, USA).

\section{Microorganisms}

Fungal and bacterial strains were obtained and stored in the freezer at $-80^{\circ} \mathrm{C}$ in the Laboratory for Applied Toxinology (LETA), of the Butantan Institute (São Paulo, Brazil). Staphylococcus aureus ATCC 29213 (Gram-positive bacteria), Escherichia coli D31 (Gramnegative bacteria); Aspergilus niger (Filamentous fungus - isolated from bread); and Cryptococcus neoformans yeast strain A serotype (CFP registration 55 (WM $148=\mathrm{VNI}$ ) were used. The Cryptococcus neoformans strain was granted by Dra. Marcia Melhem from the Adolfo Lutz Institute, Brazil - São Paulo.

\section{Antimicrobial Assays and Minimal Inhibitory Concentration (MIC)}

Antimicrobial activities of the fractions were evaluated by a liquid growth inhibition assay (Bulet et al., 1993). A suspension of the microorganisms collected in the mid-logarithmic growth phase was used. Bacteria strains were cultured in poor broth nutrient medium (PB: $1.0 \mathrm{~g}$ peptone in $100 \mathrm{~mL}$ of water containing $86 \mathrm{mM} \mathrm{NaCl}$ at pH 7.4; $217 \mathrm{mOsM}$ ); for the fungi and yeast strains were cultured in potato dextrose broth (1/2-strength PDB) $\left(1.2 \mathrm{~g}\right.$ potato dextrose in $100 \mathrm{~mL}$ of $\mathrm{H}_{2} \mathrm{O}$ at $\mathrm{pH}$ 5.0; 79 mOsM).

Determination of antimicrobial activity was performed using 5 -fold microtiter broth dilution assay in 96-well sterile plates at a final volume of $100 \mu \mathrm{L}$. A mid-log phase culture were diluted to a final concentration of $5 \times 10^{4} \mathrm{CFU} / \mathrm{mL}$ for bacteria and $5 \times 10^{5} \mathrm{CFU} / \mathrm{mL}$ for fungus and yeast (Bulet, 2008; Hetru and Bulet, 1997). Sterile water and PB or PDB were used as growth control, and Streptomycin antibiotic $(10.0 \mathrm{mg} / \mathrm{mL})$ was used as growth inhibition control. Microtiter plate 
were incubated for 18 and $24 \mathrm{~h}$ for bacteria and fungi/yeast, respectively, at $30^{\circ} \mathrm{C}$; growth inhibition was determined by measuring absorbance at $595 \mathrm{~nm}$.

The minimum inhibitory concentration (MIC) are expressed as the interval of the concentration $[a]-[b]$, where $[a]$ is the highest tested concentration at which the microorganism grow, and $[b]$ is the lowest concentration which causes a growth inhibition of $100 \%$ (Bulet et al., 1993). The assay was performed using a serial dilution and duplicate in 96 -well sterile plate; at 20 $\mu \mathrm{L}$ stock solution was used in each microtiter plate well and added to $80 \mu \mathrm{L}$ of the microorganism dilution (Silva et al., 2000; Lorenzini et al., 2003; Riciluca et al., 2012).

\section{Determination of Hemolytic Activity}

The hemolytic activity of the fractions with antimicrobial activity was assessed against human erythrocytes from a health adult donor. The Ethics Committee was the University of São Paulo School of Medicine (USP - FMUSP), $\mathrm{n}^{\circ}$ 18794419.7.0000.0065. The erythrocytes were collected in $0.15 \mathrm{M}$ citrate buffer, $\mathrm{pH} 7.4$, and washed three times by centrifugation $(700 \times \mathrm{g}, 10$ $\min , 4^{\circ} \mathrm{C}$ ) with $0.15 \mathrm{M}$ phosphate buffer saline (PBS - $35 \mathrm{mM}$ phosphate buffer, $0.15 \mathrm{M} \mathrm{NaCl}, \mathrm{pH}$ 7.4), and ressuspended in PBS to a final $3 \%(v / v)$ concentration.

Aliquots of $50 \mu \mathrm{L}$ of each fraction were added to $50 \mu \mathrm{L}$ of $3 \%(\mathrm{v} / \mathrm{v})$ suspension erythrocytes in the well of $\mathrm{U}$ - shaped bottom plates and incubated for $1 \mathrm{~h}$ at $37^{\circ} \mathrm{C}$ (with a final volume of 100 $\mu \mathrm{L}$ ). The supernatant was first collected and hemolysis was measuring the absorbance at $405 \mathrm{~nm}$ of each well in a Victor ${ }^{3}$ (1420 Multilabel Counter/ Victor ${ }^{3}$, Perkin Elmer). The hemolysis percentage was expressed in relation to a $100 \%$ lysis control (erythrocytes incubated with $0.1 \%$ triton X-100) (Sigma-Aldrich, St. Louis, MO, USA); PBS was used as negative control. The fractions was tested serial dilution and duplicate, and calculation was made according to the fallowing equation: \%hemolysis $=($ Abs sample - Abs negative $) /($ Abs positive - Abs negative $)$ (Riciluca et al., 2012; Díaz-Roa et al., 2018; Segura and Silva Junior,2018).

\section{Sodium Dodecyl Sulfate-Polyacrylamide Gel (SDS-PAGE)}

Sodium dodecyl sulfate-polyacrylamide gel electrophoresis (SDS-Page) was carried out. This experiment was performed, with modifications, based on the protocol described by Laemmli (1970). The fraction Ovipin (455 $\mu \mathrm{g}$ ) were analyzed under non-reducing conditions (without the presence $\beta$-mercaptoetanol) and diluted in four times concentrated buffer $\left(250 \mathrm{mmol}^{-1} \mathrm{~L}^{-1} \mathrm{Tris}-\mathrm{HCl}\right.$ 
pH 6.8; 300 mmol.L $\mathrm{L}^{-1}$ SDS; 1 mmol. $\mathrm{L}^{-1}$ bromophenol blue; $40 \%$ glycerol), and heated at $90^{\circ} \mathrm{C}$ for about 2 minutes. The stacking gel and the running gel were prepared in the concentrations $4.5 \%$ and $12 \%$ of the polyacrylamide, respectively. The constant voltage and temperature utilized was $120 \mathrm{~V}$ at $4^{\circ} \mathrm{C}$, and the total running time was $3 \mathrm{~h}$. As a molecular weight marker was used See Blue (Thermo Fisher Scientific Inc.). And the proteins were stained with Coomassie Blue R-250 (Laemmli,1970).

\section{Mass Spectrometry}

The fractions that showed antimicrobial activity were analyzed by positive mode mass spectrometry LC-MS/MS on a LTQ XL (Thermo Scientific). The fractions (10 $\mu \mathrm{L}$ of which) were concentrated and ressuspended in $10 \mu \mathrm{L}$ Formic Acid $0,1 \%$. The liquid chromatography was perfomed in a C18 column ( $13 \mathrm{~cm} ; 75 \mu \mathrm{m}$, i. d. $\times 100 \mathrm{~mm}-3 \mu \mathrm{m}$ from Waters), using a 5 to $95 \% \mathrm{~B}$ in 25 minutes with solvents $A: 15 \%$ in acidified water $(0,1 \%$ TFA) and B: $95 \%$ in acidified water $(0.1 \% \mathrm{TFA})$ for $2 \mathrm{~min}$; with flow of $300 \mathrm{~nL} / \mathrm{min}$, voltage of $2.5 \mathrm{kV}$ at $200^{\circ} \mathrm{C}$. The full scan was performed with $\mathrm{m} / \mathrm{z}$ of 100 a 2000 , occurring MS/MS-CID, and parameters of five most intense ions, with isolation width of $2 \mathrm{~m} / \mathrm{z}$ at CID (collision energy at 35).

\section{Database Search}

The resulting spectra in "*.RAW", format were collected and processed using MSconvert software (Chambers et al., 2012). Thus, they were converted to the mascot generic format ("*.MGF*") and thus analyzed into database searches using the Mascot tool (Perkins et al., 1999). The MS/MS peak list files were submitted to an in - house version of the Mascot server (Matrix Science, United States) and screened against the Uniprot database. PEAKS Studio Software (version 8.5, Bioinformatics Solutions Inc., Waterloo, Ontario, Canada) de novo sequencing/database search used for establishing sequence. Analysis involved $10 \mathrm{ppm}$ error tolerance for precursor ions and 0.6 $\mathrm{Da}$ for fragment ions. Oxidation was considered a variable modification.

The physicochemical parameters of which the fraction (such as the total number of positively and negatively charged residues, molecular weight, and theoretical pl) were calculated 
using the ProtParam tool, available through the portal ExPASy of the Swiss Institute of Bioinformatics website (https://web.expasy.org/protparam/) (Gasteiger et al., 2005).

\section{Results}

\section{Fractionation of Peptides from the Extract of the Chicken Eggs}

After acid extraction of the crude extract from the chicken eggs Gallus gallus domesticus. The acid extract was applied to Sep-Pak ${ }^{\circledR} \mathrm{C} 18$ cartridges for pre-fractionation. The supernatant were eluted by three successive concentrations of acetonitrile (ACN) (5\%, 40\% and $80 \%)$ in acidified water ( $0.1 \%$ TFA). All the material at $80 \%$ ACN was subjected and analyzed by RP-HPLC (Figure 1A), and the fractions obtained was lyophilized, suspended in ultrapure water $(1 \mathrm{~mL})$ and tested against Staphylococcus aureus, Escherichia coli, Aspergillus niger, and Cryptococcus neoformans in a liquid growth inhibitory assay. The searched for the eluted $80 \%$ ACN showed the presence of six fractions $(9,11,20,21,22$ and 24) with antimicrobial activity (Table 1).

Table 1. Antimicrobial activity fractions from elution $80 \%$ ACN Chicken eggs.

\begin{tabular}{|c|c|c|c|c|}
\hline \multicolumn{5}{|c|}{ Microorganisms } \\
\hline & \multicolumn{2}{|c|}{ Fungus } & \multicolumn{2}{c|}{ Bacteria } \\
\cline { 2 - 5 } & Filamentous & Yeast & Gram-positive & Gram-negative \\
\hline Fractions & A. niger & C. neoformans & S. aureus & E. coli \\
\hline 9 & - & + & - & - \\
\hline 11 & + & + & - & - \\
\hline 20 & + & + & + & + \\
\hline 21 & + & + & + & + \\
\hline 22 & + & + & + & - \\
\hline 24 & + & + & - & \\
\hline
\end{tabular}

Symbol (+) fraction showed antimicrobial activity; Symbol (-) fraction do not showed antimicrobial activity. 


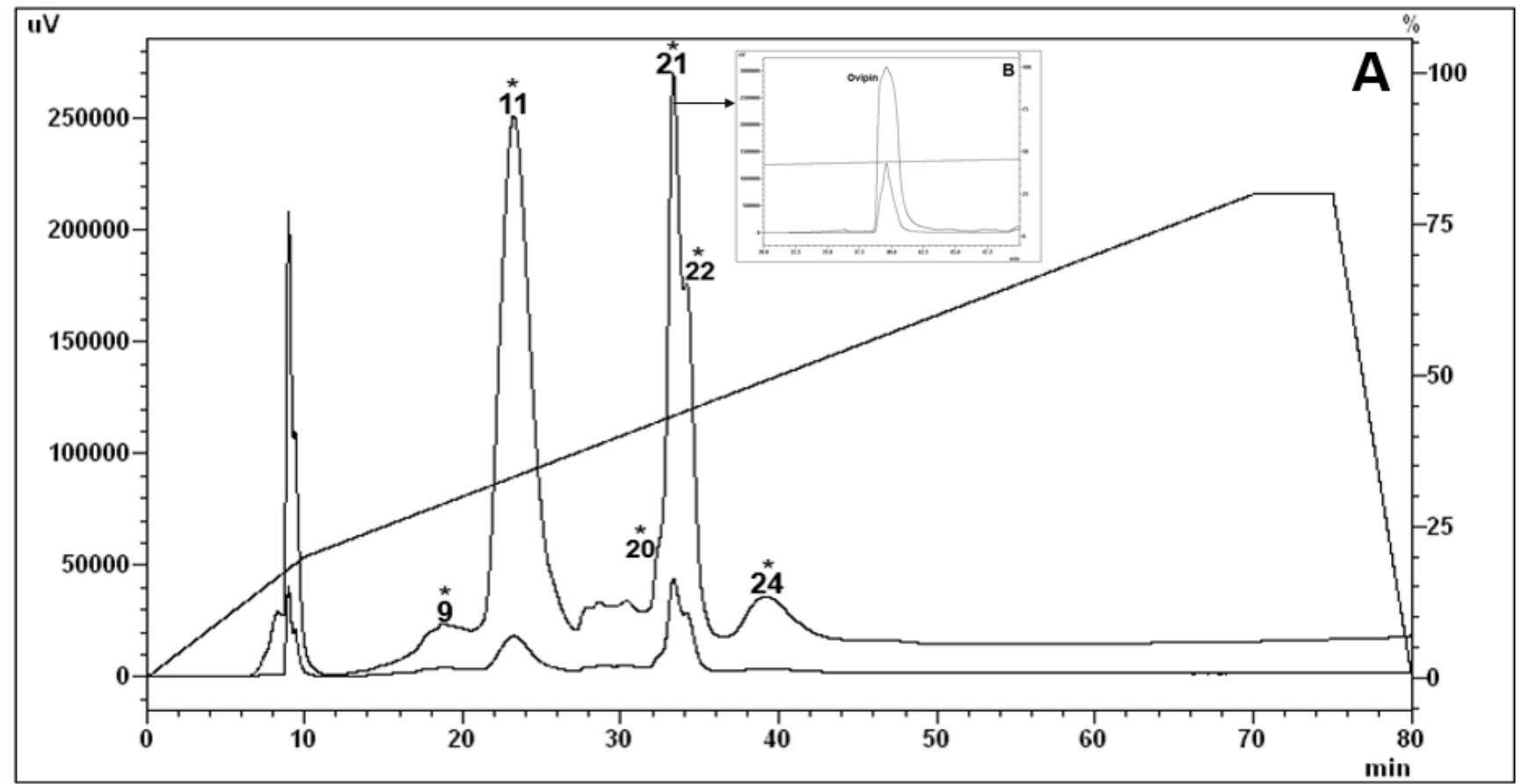

FIGURE 1 | Reversed-phase high-performance liquid chromatograph (RP-HPLC) of the Chicken Eggs Gallus gallus domesticus extract eluted with $80 \%$ acetonitrile (ACN). After the pre-fractionation in a Sep-Pak C18 column, the fraction was eluted with $80 \%$ ACN were subjected to a Shim-Pack ODS C18 (20 x $250 \mathrm{~mm}, 300 \AA$, $10 \mu \mathrm{m})$; Solvents System: Solvent A: $0.1 \% \mathrm{TFA} / \mathrm{H}_{2} \mathrm{O}$ and Solvent B: $0.1 \% \mathrm{TFA} / \mathrm{ACN}$ with a linear gradient $20 \%$ to $80 \% \mathrm{ACN}, 60 \mathrm{~min}$ at 8 $\mathrm{mL} / \mathrm{min}$ flow rate. (A)The fraction 21 indicated by an asterisk $\left(^{*}\right)$ had antimicrobial activity against microorganisms tested. (B) Ovipin, indicated with an arrow, using same column and solvents system: Solvent $\mathrm{A}: 0.05 \% \mathrm{TFA} / \mathrm{H}_{2} \mathrm{O}$ and Solvent B: $0.05 \%$ TFA/ACN. Ovipin was eluted from linear gradient $39 \%$ to $49 \%$ ACN, for $60 \mathrm{~min}$ at $2 \mathrm{~mL} / \mathrm{min}$ flow rate. Both runs the absorbance was monitored at $225 \mathrm{~nm}$.

\section{Antimicrobial Activity and Minimum Inhibitory Concentration (MIC)}

The antimicrobial activity occurred in the fraction 21 eluted with retention time range of 32.7-34.1 min (Figure 1A). This fraction was submitted to a second step of fractionation and showed only one a pronounced antimicrobial fraction: named Ovipin (Figure 1B). The name to choice for which fraction referring the chicken eggs species Galus gallus domesticus.

The concentration of Ovipin peptide was determined based on the Lambert-Beer Law using the molar extinction coefficient at $205 \mathrm{~nm}$ absorption (Anthis and Clore, 2013), obtained using the Protein Parameter Calculator tool available at the Nick Anthis website (http://nickanthis.com/tools/a205.html; accessed on 15 September 2021)

Ovipin peptide inhibited the growth of M. luteus A270 $1.94 \mu \mathrm{M}(2.84 \mu \mathrm{g} / \mathrm{mL})$, A. niger 31.01 $\mu \mathrm{M}(45.5 \mu \mathrm{g} / \mathrm{mL})$, C. neoformans VNI (WM 148) $15.51 \mu \mathrm{M}(22.75 \mu \mathrm{g} / \mathrm{mL})$ (Table 2). 
Table 2. Antimicrobial activity spectrum of Ovipin peptide.

\begin{tabular}{|c|c|}
\hline Microorganisms & MIC $(\boldsymbol{\mu M}(\boldsymbol{\mu g} / \mathbf{m L}))^{\mathbf{}}$ \\
\hline Gram-positive bacteria & $1.94(2.84)$ \\
\hline Micrococcus luteus A270 & ND \\
\hline Gram-negative bacteria & $45.5(31.01)$ \\
\hline Escherichia coli D31 & \\
\hline Fungi & $22.75(15.51)$ \\
\hline Aspergillus niger \\
Yeast & \\
\hline $\begin{array}{c}\text { Cryptococcus neoformans VNI (WM } \\
148)\end{array}$ & \\
\hline
\end{tabular}

MIC, minimum inhibitory concentration $(\mu \mathrm{g} / \mathrm{mL})$ : $\mu \mathrm{M}$. ND, not detectable (antimicrobial activity not detected in the concentrations assayed). ${ }^{1}$ The MIC refers to the concentration necessary to achieve a growth inhibition of $100 \%$.

\section{Hemolytic Activity}

To determine the effect of the Ovipin peptide on human erythrocytes at the antimicrobial concentrations, its hemolytic activity was tested. After incubating red blood cells from a healthy donor with Ovipin (124.05 $\mu \mathrm{M}$ up to $0.24 \mu \mathrm{M})$ concentrations for $1 \mathrm{~h}$ at $37^{\circ} \mathrm{C}$. No hemolytic activity was observed, demonstrated that Ovipin does not cause significant hemolytic effect against of human erythrocytes within these concentrations (Figure 2) (Yacoub et al., 2014). And the electrophoretic profile (data not show) of this peptide (up to $455 \mu \mathrm{g}$ ) could not observe bands in this gel concentration (12\% polyacrilamide).

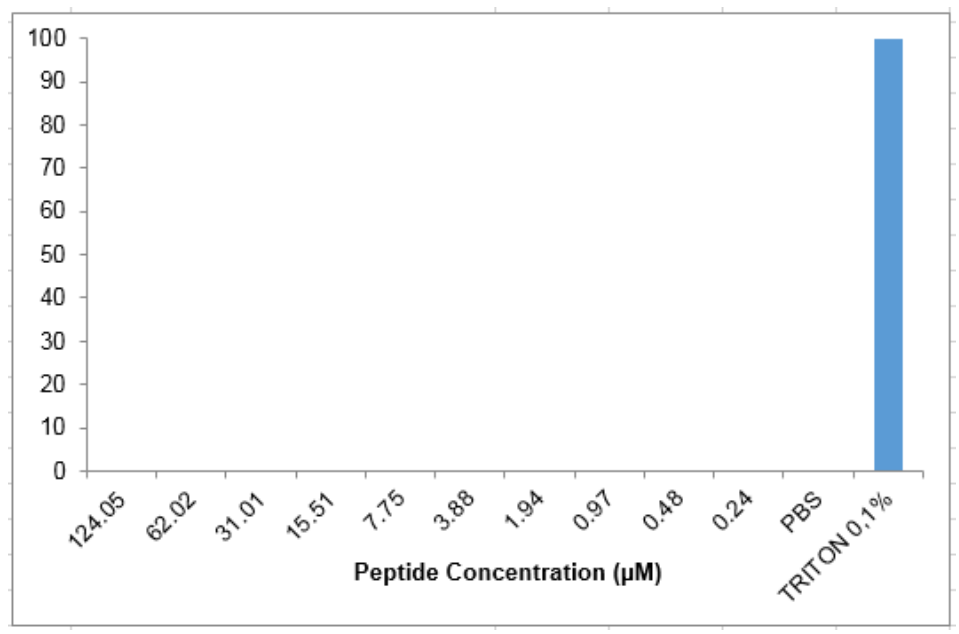

FIGURE 2 | Hemolytic Activity of the Ovipin peptide incubated with human erythrocytes in different concentrations of the peptides. Serial dilution and duplicated was performed, for $1 \mathrm{~h}$ at $37^{\circ} \mathrm{C}$. The hemolysis percentage was expressed in relation to $0 \%$ hemolysis with PBS and $100 \%$ lysis control $(0.1 \%$ triton X-100) 


\section{Mass Spectrometry and Characterization of Ovipin Peptide}

70

When analyzed the Ovipin peptide using the MASCOT ${ }^{\circledR}$ software to search the Gallus gallus database, revealed a mass of 1,581.9494 $\mathrm{Da}$ and with high identity with a fragment from the Apolipoprotein B (Apo-B) of Gallus gallus. The complete Ovipin aa sequence obtained by PEAKS de novo sequencing showed 15 amino acid sequence do not having post-translational modification (PTM). Collision-induced dissociation (CID) spectrum from mass/charge $(\mathrm{m} / \mathrm{z})$ of its double charged ion give $[\mathrm{M}+2 \mathrm{H}]^{2+}, \mathrm{m} / \mathrm{z} 792.3484$ (Figure 5). Characterizing the peptide's primary structure with the MASCOT tool gave the YVSPVAIVKGLNIPL sequence.

\section{MATRIX
SCIENCE Mascot Search Results}

\section{Peptide View}

MS/MS Fragmentation of YVSPVAIVKGLNIPL

Found in F1NV02 in Gallus_gallus, Apolipoprotein B OS=Gallus gallus GN=APOB PE=4 SV=2

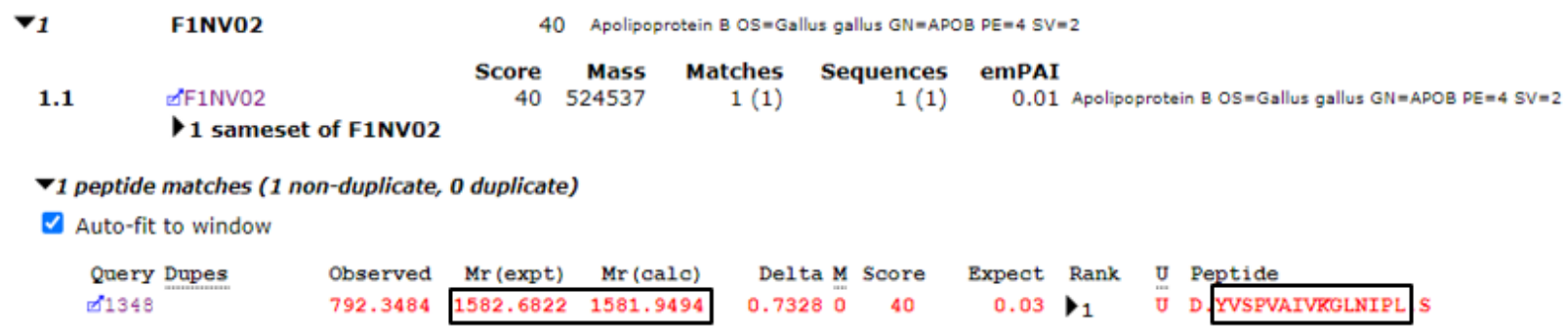

Figure 3: Result obtained in searches databases using the tool Mascot® (Matrix Science). The Ovipin peptide is similar with a fragment from the Gallus gallus Apolipoprotein B (APO B)

$>$ Tr|F1NV02|F1NN02_CHICK Apolipoprotein B OS=Gallus gallus OX=9031 GN=APOB PE=4 SY=2

1 MGPVQLLLLL LLLSSGVLTQ EGTPENGNPG CSKDAARFKS LRKYVYLYEA ETSSGITGTA DSHSGSKITC KVELEVPQLC QFILRTMHCS

91 LRETFGVDSE RRAMLRKSKN SDDFANAMSK HELRFSTQDG TKVKLYPEKD EPLNVLNLKR GIISALLAPT ETEENIKTIS MDTVYGKCDS

181 EVEFKSRRGS VAEDISINRN LKACDNFSPI RDYVSPVAIV KGLNIPLSTL LSSTQSCHYS IDAKKKHIRD VVCSEKHLFL PSSYKNQYGM

271 MTEVNQTLKL EDNQRMNNRN PDGDELEEKG LALESTDAKF SRQGDAVLKI LQELQKLTAS QQNQQRAKLF YKFVSGLRSL HNSTLGSLVP 361 KMMETSSSIT IQALIQCGTP ECYSAVLQIL RTGNVNPLVV DLVTYTLGLL PSPTPKRIRE ILNMAQYQPS RASFYGLSHA VTKFYSEKMI 451 VTEEITDVAD FMVSLLGTDC SGDAELTYLT LRAIGNMGAV MEKAKPSLKA SLKTCIRNQA ASLSVQKAAI QAFRKMTITE EDRSALLKEF 541 QEGDAPTDKR LATYLILMKN PSPADLAKIM RILTREKNEQ VKSEVASHIA NILDSDEVGI EDLKSHVEEA LKGNEVPTAK DERKESQNYQ

Figure 4: Peptide spectrum match indicated by a blue line below the sequence of the Apolipoprotein B of Gallus gallus. Ovipin covered $2 \%$ of the whole protein sequence. 


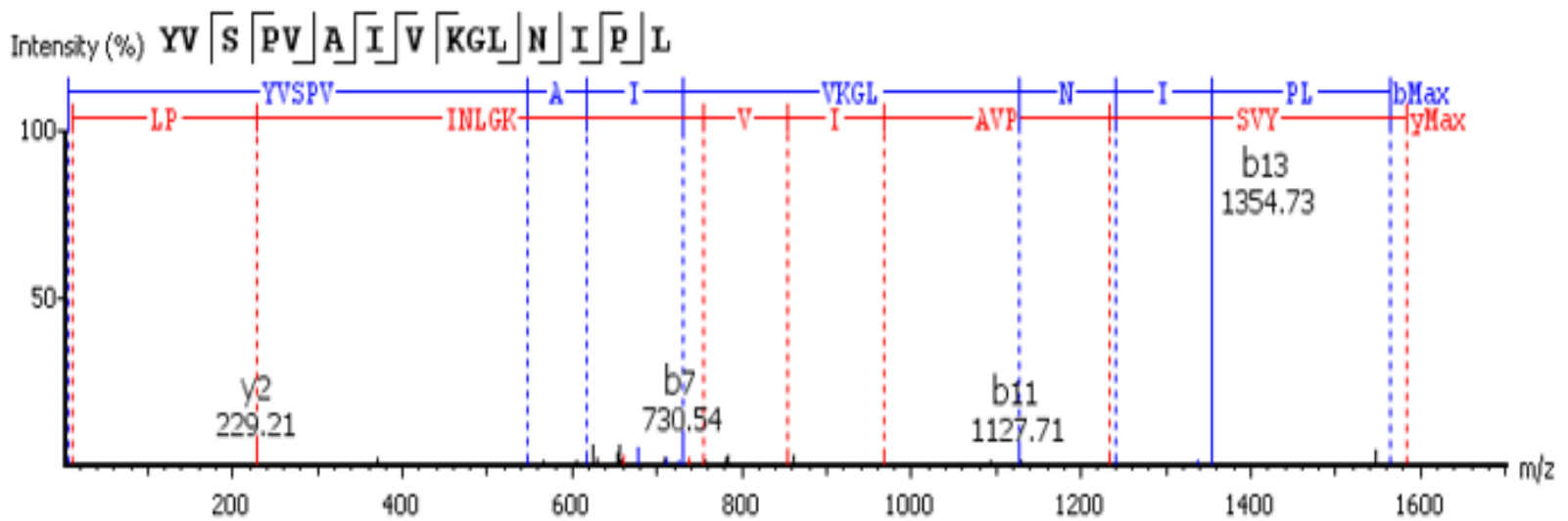

Figure 5: Collision-induced dissociation (CID) spectrum of de novo sequencing antimicrobial peptide, Ovipin. The ions belonging to $-\mathrm{y}$ (red) and $-\mathrm{b}$ (blue) series indicated in the spectrum correspond to the amino acid sequence of the peptide: YVSPVAIVKGLNIPL. The fragments of the sequenced peptide are represented by standard amino acid code letters.

Knowing the sequence, some tools were used predicting Ovipin significant physicochemical characteristics. ExPASY's (SIB Bioinformatics Resource Portal) PepDraw and Pep-Calc.com sequence analysis yielded a potential peptide isoelectric point (pl), molar extinction coefficient and net (Table 3).

The peptide was predicted to have one Lys positively-charged aa residue and six of the 15 aa were predicted to be hydrophobic (2 Ile, 2 Leu and $3 \mathrm{Val}$ ), showed hydrophobic ratio of $53 \%$ and suggesting poor water solubility for Ovipin. ExPASy's ProtParam tool predicted that the peptide would intact for up 2.8 hours in mammalian reticulocytes (in vitro), 10 min in yeast (in vivo) and 2 min in Escherichia coli (in vivo). This was likely due to the presence of a Tyr (Y) residue at the N-terminus.

Table 3: Ovipin theoretical physicochemical properties.

\begin{tabular}{|cc|}
\hline \multicolumn{2}{|c|}{ Peptide Properties } \\
\hline Sequence: & YVSPVAIVKGLNIPL \\
Lenght: & 15 \\
Mass: & 1581.9494 \\
Isoelectric point $(\mathrm{pl}):$ & 9.49 \\
Net charge at $\mathrm{pH}:$ & 1 \\
Hydrophobicity: & $+7.11 \mathrm{Kcal}^{*} \mathrm{~mol}^{-1}$ \\
Estimated solubility: & Poor water solubility \\
Extinction coefficient: & $1280 \mathrm{M}^{-1} \mathrm{~cm}^{-1}$ \\
\hline
\end{tabular}

Physicochemical parameters were calculated using ExPASy PepDraw and Pep-Calc.com 
A BLAST (basic local alignment search tool) was used to identify a multiple alignment analysis of the peptide sequence Ovipin using Clustal Omega program. The BLAST searches and the alignments showed 100\% sequence similarity with the fragment Apolipoprotein B of Gallus gallus, and $93.3 \%$ of similarity with fragments Apolipoprotein B with others five species of Aves, being Patagioenas fasciata monilis, Amazona aestiva, Tinamus guttatus, Aptenodytes forsteri and Egretta garzetta (Figure 6).

16

Origin
Gallus gallus
Gallus gallus
Patagioenas fasciata monilis
Amazona aestiva
Tinamus guttatus
Aptenodytes forsteri
Egretta garzetta

Figure 6: Alignment of the amino acid sequence of Ovipin. Using the Clustal Omega alignment, the Ovipin sequence was aligned with fragments of the Apolipoproteins of the Gallus gallus and others Aves species. Regions that show identical amino acid among all species are identified in dark red or $\left({ }^{*}\right)$, and minor modifications are show in light red (:). Clustal Omega (http://www.ebi.ac.uk/Tools/msa/clustalo/; accessed on 24 January 2020) modified manually.

Table 4. Known antimicrobial peptides having similarity with Ovipin, as identified in the Antimicrobial Peptide Database (APD2) (Wang et al., 2009).

\begin{tabular}{|c|c|c|c|c|}
\hline Peptide Name & Sequence Alignment & Source Organism & APD Identifier & Percentage Similarity \\
\hline Temporin-1SKa (17 aa) & $\begin{array}{l}\text { FLPVILPV+IGKLLNGI+L } \\
++Y V+S P V A I V K G L N+I P L\end{array}$ & Frog Rana sakuraii & AP01924 & 47,36 \\
\hline Temporin-1GY (13 aa) & $\begin{array}{l}+ \text { VIP++IVSGLLSSLL } \\
\text { YVSPVAIVKG+LNIPL }\end{array}$ & $\begin{array}{c}\text { Frogs } \\
\text { Pelophylax } \\
\text { nigromaculatus }\end{array}$ & AP02223 & 43,75 \\
\hline Temporin-1TGc (17 aa) & $\begin{array}{l}\text { FLPVILPV+IGKLLSGI+L } \\
++Y V+S P V A I V K G L+N I P L\end{array}$ & Rana sakuraii & AP01268 & 42,1 \\
\hline Peptide AN5-1 (12 aa) & $\begin{array}{l}Y S K S L P+L S V++L N+P+ \\
Y+V S+P V A I V K G L N I P L\end{array}$ & $\begin{array}{l}\text { Paenibacillus } \\
\text { alvei AN5 }\end{array}$ & AP02193 & 41,17 \\
\hline
\end{tabular}

The Antimicrobial Peptide Database (APD) prediction tool was used to align Ovipin 


\section{Discussion}

The abundance of multidrug-resistance of the microorganisms has emerged, increasing the spectrum of untreatable infections and triggering a worldwide public health problem (Gaglione et al., 2011; Blair et al., 2015). The accelerated growth of antimicrobial resistance has created a great interest in the discovery for new compounds more effective, mainly with antimicrobial action, to be used as tools for antimicrobial therapies (Diaz-Roa et al., 2018; Chernysh et al., 2015)

During the hatched time, eggs are constantly attacked by a variety of microorganisms that decrease their chances of survival and viability. (Packard \& Packard, 1980). The compounds isolated from eggs showed a broad spectrum of antimicrobial activity, mainly against bacteria's (D'Alba \& Shawkey, 2015). In the present work we isolated and characterize a peptide, denoted Ovipin, from chicken eggs Gallus gallus domesticus, its antimicrobial activity, biochemical and structural properties were evaluated.

Ovipin presented a good antimicrobial activity $(\mathrm{MIC}=1.94 \mu \mathrm{M}(2.84 \mu \mathrm{g} / \mathrm{mL}))$ against Micrococcus luteus (Gram-positive bacteria). In the work of Memarpoor-Yazdia and Chamania (2012), was identified from hydrolyzed lysozyme, the F2 peptide (MW 1753.98 Da) that was active against Leuconostoc mesenteroides (Gram-positive bacteria) and Escherichia coli (Gram-negative bacteria). Mine et al. (2004) also isolated and identified from hydrolyzed lysozyme, the peptide F1d (MW $1185 \mathrm{Da}$ ), with antimicrobial activity against Escherichia coli K-12, and the peptide F3b (MW $875 \mathrm{Da}$ ) that was active against Staphylococcus aureus 23-394 (Gram-positive bacteria).

Ovipin showed antimicrobial activity against Aspergillus niger ( $\mathrm{MIC}=45.5 \mu \mathrm{M}(31.01$ $\mu \mathrm{g} / \mathrm{mL})$ ) and Cryptococcus neoformans strain (MIC $=22.75 \mu \mathrm{M}(15.51 \mu \mathrm{g} / \mathrm{mL}))$. The antimicrobial activity against $C$. neoformans was very interesting, because this yeast belongs to Basidiomycota phylum, and it is founded in avian excreta (mainly from pigeons) and has a strong relationship with human infections with highly incidence in immunocompromised individuals or individual that has some specific defects in immunity. According to the host's immune response, this microorganism can make changes in the metabolism itself as well as induce changes in the structure of its capsule, resulting in multidrug resistance, thus the obtaining of a molecule isolated from a food source and with the ability to inhibit this microorganism of great medical importance may result in a future candidate against infections developed by resistant microorganisms, such as $C$. neoformans (Srinkanta et al., 2014; Aspaugh, 2015). In the work Candido-Ferreira et al. (2017) was identified and characterized the Oligoventin peptide (8 amino acid residues and MW 1,061.4 $\mathrm{Da}$ ) from the eggs of the Brazilian armed spider Phoneutria nigriventer (Ctenidae, Araneomorphae). Oligoventin showed antimicrobial activity (MIC range at 47 to $188.9 \mu \mathrm{M}$ ) against 
Gram-positive and Gram-negative bacteria, as also yeast (Candida albicans MDM8). The molecule shows $4,3 \%$ of hemolysis against human erythrocytes at $188.9 \mu \mathrm{M}$ and $2 \%$ at $94.5 \mu \mathrm{M}$. Therefore, it is worth pointing out that both Ovipin and Oligoventin, although islolated from eggs of different animals, have antimicrobial action against opportunistic pathogens of great medical importance.

Ovipin showed to have 1,581.9494 Da and similarity of 93.3 to $100 \%$ with Apoliproteins B of the five groups of Aves. Very low-density lipoproteins (VLDL) are precursors low-density lipoproteins (LDL) of eggs yolk. VLDL II and apo B are mainly proteins that constituted VLDL. The molecular weight of apo B is $500 \mathrm{kDa}$, showed only one structural unit and $64 \%$ of the similarity with human apo B-100. When transferred into the yolk, the apo B undergoes enzymatic cleavages, forming news fragments (Jolivet et al., 2006), which may have new functions in the yolk.

The apolipoproteins are recognized as source bioactive-peptides showed broad antimicrobial or antiviral activity (Gaglione et al. (2017). In the work Zambrovicz et al., (2015) was identified four peptides with molecular weight ranging from 1,210.62 to 1,677.88 Da obtained from Apoliproteins B, Vitellogenin-2 and Apovitelenin-1, all proteins localized in chicken egg yolk. In relation the peptides identified from Apolipoprotein $B$, one peptide showed amino acid sequence YINQMPQKSRE (MW: 1,393.774 Da) and the other peptide showed amino acid sequence YINQMPQKSREA (MW: 1,464.813). In this study not was evaluated the antimicrobial activity this peptides, but was demonstrated the antioxidant activity, ACE inhibitory and/or antidiabetic activities. The peptide YINQMPQKSRE demonstrated the strongest antioxidant, and the DPPH free radical scavenging and iron chelating activities reached $2.3 \mu \mathrm{M}$ Trolox eq/mg and $37.4 \mu \mathrm{g}$ $\mathrm{Fe}^{2+} / \mathrm{mg}$, respectively. The peptide showed YINQMPQKSREA the highest ferric reducing activity $\left(76.0 \mu \mathrm{g} \mathrm{Fe}{ }^{2+} / \mathrm{mg}\right)$, an activity very strong ACE $\left(\mathrm{IC}_{50}=10.1 \mu \mathrm{g} / \mathrm{mL}\right)$ and DPP-IV $\left(\mathrm{IC}_{50}=222.8\right.$ $\mu \mathrm{g} / \mathrm{mL}$ ) inhibitory activity. So, even though the antimicrobial activity of these peptides has not been evaluated, they have important biological activities that can be used as possible multifunctional candidates.

\section{Conclusions}

The identification and characterization of new antibiotics agents can lead to the development of new compounds that act against resistant pathogenic microorganisms. In this work, we isolated, purified and characterized Ovipin peptide from the chicken eggs Gallus gallus 
domesticus. The peptide has a molecular weight of 1,581.9494 $\mathrm{Da}$ and was able to inhibit the growths of Gram-positive bacteria, Filamentous fungi and Yeast.

Further studies are needed to evaluate the action of this peptide against other pathogenic microorganisms, such as bacteria, fungi, viruses and parasites, as well as to investigate its mechanism of action, if it has antioxidant activity and activity against ACE.

Finally, in addition to their great contribution to food, chicken eggs have become increasingly important in the discovery of new peptides that act against antimicrobial resistance, as well as other important biological activities, they can be used as tools for areas of biotechnology and pharmacology.

Author Contributions: Conceptualization, SRS, AM and PISJ; Data curation, SRS; Formal analysis, AM and PISJ; Funding acquisition, AM and PISJ; Investigation, SRS; Methodology, AM and PISJ.; Project administration, AM and PISJ; Resources, PISJ; Supervision, PISJ and AM; Validation, SRS, AM and PISJ; Writing-original draft, SRS; Writing-review and editing, SRS, AM and PISJ.

Funding: This work was supported by the Research Support Foundation of the State of São Paulo (FAPESP/CeTICS) [Grant No. 2013/07467-1]; the Brazilian National Council for Scientific and Technological Development (CNPq) [Grant No. 472744/2012-7]; and the Coordination for the Improvement of Higher Education Personne (CAPES) [Grant No. 1646478].

Ethical Approval: This research was approved and performed in accordance with the Ethical Principles in Animal Research adopted by the Ethics Committee for the Use of Animals of UNIFESP - CEUA No 9183300118 and Plataforma Brasil CAAE N ${ }^{\circ}$ 18794419.7.0000.0065 and was approved.

Data Availability Statement: The data that support the findings of this study are presented in the main manuscript or in the supplementary material of this article.

Acknowledgments: We would like to thank Caroline Correa, Marta Gomes, Rogerio Lauria and Sinval Gregorio laboratory technicians from the Biophysics Department at Unifesp for all their help with peptide synthesis. Professor Dr. Edgar Julian Paredes Gamero, and his students Heron and Wagner at Unifesp, for the opportunity to learn about the development of the antitumor study. Cryptococcus neoformans VNI (WM148) was kindly provided by Dra Márcia Melhem - Instituto Adolfo Lutz - São Paulo/SP, Brasil.

Conflicts of Interest: “The authors declare no conflict of interest”.

\section{References}

Andreu, D. e Rivas, L. Animal antimicrobial peptides: an overview. Biopolymers, 47 (6) 415-433 (1998).

Anthis, N.J.; Clore, G.M. Sequence-specific determination of protein and peptide concentrations by absorbance at $205 \mathrm{~nm}$. Protein Sci. 2013, 22, 851-858.

Antimicrobial-peptide-database. Available online: http://aps.unmc.edu/AP/prediction/prediction main.php (accessed on 12 September 2020).

Aspaugh, J.A. Virulence mechanisms and Cryptococcus neoformans pathogenesis. Fungal Genet Biol. 2015 May ; 78: 55-58. doi:10.1016/j.fgb.2014.09.004.

Bahar, A.A.; Ren, D. Antimicrobial peptides. Pharmaceuticals (Basel), 6 (12) 1543-1575 (2013). 
Brogden, K.A. Antimicrobial peptides: pore formers or metabolic inhibitors in bacteria? Nat Rev Microbiol, 3 (3) 238250 (2005).

Bulet, P. Strategies for the discovery, isolation, and characterization of natural bioactive peptides from the immune system of invertebrates. Methods Mol. Biol. 2008, 494, 9-29. [CrossRef] [PubMed]

Bulet, P., Dimarcq, J.L., Hetru, C., Lagueux, M., Charlet, M., Hegy, G., Van Dorsselaer, A. e Hoffmann, J.A. A novel inducible antibacterial peptide of Drosophila carries an O-glycosylated substitution. J Biol Chem, 268 (20) 1489314897 (1993).

Candido-Ferreira, I.L.; Kronenberger, T.; Sayegh, R.S.R.; Batista, I.F.C.; Silva Jumior, P.I. Evidence of an antimicrobial peptide signature encrypted in HECT E3 uniquitin ligases. Front Immunol 2017 Jan 9;7:664. doi: 10.3389/fimmu.2016.00664. eCollection 2016.

Chambers, M.C., Maclean, B., Burke, R., Amodei, D., Ruderman, D.L., Neumann, S., Gatto, L., Fischer, B., Pratt, B., Egertson, J., Hoff, K., Kessner, D., Tasman, N., Shulman, N., Frewen, B., Baker, T.A., Brusniak, M.Y., Paulse, C., Creasy, D., Flashner, L., Kani, K., Moulding, C., Seymour, S.L., Nuwaysir, L.M., Lefebvre, B., Kuhlmann, F., Roark, J., Rainer, P., Detlev, S., Hemenway, T., Huhmer, A., Langridge, J., Connolly, B., Chadick, T., Holly, K., Eckels, J., Deutsch, E.W., Moritz, R.L., Katz, J.E., Agus, D.B., MacCoss, M., Tabb, D.L. e Mallick, P. A cross-platform toolkit for mass spectrometry and proteomics. Nat Biotechnol, 30 (10) 918-920 (2012).

Cruz, J., Ortiz, C., Guzman, F., Fernandez-Lafuente, R. e Torres, R. Antimicrobial peptides: promising compounds against pathogenic microorganisms. Curr Med Chem, 21 (20) 2299-2321 (2014).

Diaz-Roa, A., Patarroyo, M.A., Bello, F.J. e Da Silva, P.I., Jr. Sarconesin: Sarconesiopsis magellanica Blowfly Larval Excretions and Secretions With Antibacterial Properties. Front Microbiol, 92249 (2018).

Ercan, D. e Demirci, A. Recent advances for the production and recovery methods of lysozyme. Crit Rev Biotechnol, 36 (6) 1078-1088 (2016).

Gaglione R, Dell'Olmo E, Bosso A, Chino M, Pane K, Ascione F, Itri F, Caserta S, Amoresano A, Lombardi A, Haagsman HP, Piccoli R, Pizzo E, Veldhuizen EJA, Notomista E, Arciello A. Novel human bioactive peptides identified in Apolipoprotein B: Evaluation of their therapeutic potential. Biochem Pharmacol. 2017 Apr 15;130:34-50. doi: 10.1016/j.bcp.2017.01.009. Epub 2017 Jan 25. PMID: 28131846.

Garcia, F.; Villegas, E.; Espino-Solis, G.P.; Rodriguez, A.; Paniagua-Solis, J.F.; Sandoval-Lopez, G.; Possani, L.D.; Corzo, G. Antimicrobial peptides from arachnid venoms and their microbicidal activity in the presence of commercial antibiotics. J. Antibiot. 2013, 66, 3-10. [CrossRef] [PubMed]

Gasteiger, E.; Hoogland, C.; Gattiker, A.; Duvaud, S.; Wilkins, M.R.; Appel, R.D.; Bairoch, A. Protein Identification and Analysis Tools on the ExPASy Server. In The Proteomics Protocols Handbook; John, M.W., Ed.; Humans Press Inc.: Totowa, NJ, USA, 2005; pp. 571-607.

Gil-Chávez, G.J.; Villa, J.A.; Ayala-Zavala, F.; Heredia, J.B.; Sepulveda, D.; Yahia, E.M.; González-Aguilar, G.A. Technologies for Extraction and Production of Bioactive Compounds to be Used as Nutraceuticals and Food Ingredients: An Overview. Comprehensive Reviews in Food Science and Food Safety, January (2013) Vol.12, Issue1, Pages 5-23.

https://doi.org/10.1111/1541-4337.12005

Guimarães, D.O.; Momesso, L. S.; Pupo, M.T. Antibiotics: therapeutic importance and perspectives for the discovery and development of new agents Quim. Nov. Vol. 33, No 3, São Paulo, (2010). http://dx.doi.org/10.1590/S010040422010000300035

Hancock, R.E. e Sahl, H.G. Antimicrobial and host-defense peptides as new anti-infective therapeutic strategies. Nat Biotechnol, 24 (12) 1551-1557 (2006).

Hetru, C.; Bulet, P. Strategies for the isolation and characterization of antimicrobial peptides of invertebrates. Methods Mol. Biol. 1997, 78, 35-49. [CrossRef] 
Ibrahim, H.R., Sugimoto, Y. e Aoki, T. Ovotransferrin antimicrobial peptide (OTAP-92) kills bacteria through a membrane damage mechanism. Biochim Biophys Acta, 1523 (2-3) 196-205 (2000).

Izadpanah A, Gallo RL. Antimicrobial peptides. J Am Acad Dermatol. 2005;52(3 Pt 1):381-392. doi:10.1016/j.jaad.2004.08.026

Jolivet, P.; Boulard, C.; Beaumal, V.; Chardot, T.; Anton, M. Protein components of low-density lipoproteins purified from hen egg yolk. J. Agric. Food Chem., 2006, 54, 4424-4429.

Kang, S.J., Park, S.J., Mishig-Ochir, T. e Lee, B.J. Antimicrobial peptides: therapeutic potentials. Expert Rev Anti Infect Ther, 12 (12) 1477-1486 (2014).

Kolaczkowska, A., Kolaczkowski, M., Sokolowska, A., Miecznikowska, H., Kubiak, A., Rolka, K. e Polanowski, A. The antifungal properties of chicken egg cystatin against Candida yeast isolates showing different levels of azole resistance. Mycoses, 53 (4) 314-320 (2010).

Kovacs-Nolan, J., Phillips, M. e Mine, Y. Advances in the value of eggs and egg components for human health. $J$ Agric Food Chem, 53 (22) 8421-8431 (2005).

Laemmli, U.K. Cleavage of structural proteins during the assembly of the head of bacteriophage T4. Nature (1970), 227, 680-685. [CrossRef] [PubMed]

Li J, Koh JJ, Liu S, Lakshminarayanan R, Verma CS, Beuerman RW. Membrane Active Antimicrobial Peptides: Translating Mechanistic Insights to Design. Front Neurosci. 2017;11:73. Published 2017 Feb 14. doi:10.3389/fnins.2017.00073

Lorenzini, D. M., Da Silva, P. I. Jr., Fogaca, A. C., Bulet, P., and Daffre, S. (2003). Acanthoscurrin: a novel glycine-rich antimicrobial peptide constitutively expressed in the hemocytes of the spider Acanthoscurria gomesiana. Dev. Comp. Immunol. 27, 781-791. doi: 10.1016/S0145-305X(03)00058-2

Memarpoor-Yazdia, M.A., A.; Chamania, J. A novel antioxidant and antimicrobial peptide from hen egg white lysozyme hydrolysates. Journal of Functional Foods, 4 (1) 278-286 (2012).

Mookherjee, N.; Hancock, R.E.W. Cationic host defence peptides: Innate immune regulatory peptides as a novel approach for treating infections. Cell. Mol. Life Sci. 64 (2007) 922 - 933. DOI 10.1007/s00018-007-6475-6

Perkins, D.N., Pappin, D.J., Creasy, D.M. e Cottrell, J.S. Probability-based protein identification by searching sequence databases using mass spectrometry data. Electrophoresis, 20 (18) 3551-3567 (1999).

Peters, B.M.; Shirtli_, M.E.; Jabra-Rizk, M.A. Antimicrobial Peptides: Primeval molecules or future drogs? PLoS Pathog. 2010, 6, e1001067. [CrossRef] [PubMed]

Riciluca, K.C., Sayegh, R.S., Melo, R.L. e Silva, P.I., Jr. Rondonin an antifungal peptide from spider (Acanthoscurria rondoniae) haemolymph. Results Immunol, 2 66-71 (2012).

Rutherfurd-Markwick KJ. Food proteins as a source of bioactive peptides with diverse functions. Br J Nutr. 2012;108 Suppl 2:S149-S157. doi:10.1017/S000711451200253X

Shai, Y. Mechanism of the binding, insertion and destabilization of phospholipid bilayer membranes by alpha-helical antimicrobial and cell non-selective membrane-lytic peptides. Biochim Biophys Acta, 1462 (1-2) 55-70 (1999).

Segura-Ramírez PJ, Silva Júnior PI. Loxosceles gaucho Spider Venom: An Untapped Source of Antimicrobial Agents. Toxins (Basel). 2018;10(12):522. Published 2018 Dec 6. doi:10.3390/toxins10120522

Silva, P.I., Jr., Daffre, S. e Bulet, P. Isolation and characterization of gomesin, an 18-residue cysteine-rich defense peptide from the spider Acanthoscurria gomesiana hemocytes with sequence similarities to horseshoe crab antimicrobial peptides of the tachyplesin family. J Biol Chem, 275 (43) 33464-33470 (2000).

Srikanta, D.; Santiago-Tirado, F.H.; Doering, T.L. Crysptococcus neoformans: Historical curiosity to modern pathogen. Yeast. 2014 February ; 31(2): 47-60. doi:10.1002/yea.2997. 
Wang, G.; Li, X.; Wang, Z. APD2: The updated antimicrobial peptide database and its application in peptide design. Nucleic Acids Res. 2009, 37, 933-937.

Zambrowicz, A.; pokora, M.; Setner, B.; Dabrowska, A.; Szoltysik, M.; Babij, K.; Szewczuk, Z.; Trziszka, T.; Lubec, G.; Chrzanowska, J. Multifunctional peptides derived from an egg yolk protein hydrolysate: isolation and characterization. Amino Acids 47, 369-380 (2015). https://doi.org/10.1007/s00726-014-1869-x

Zasloff, M. Antimicrobial peptides of multicellular organisms. Nature, 415 (6870) 389-395 (2002).

1. online: URL (accessed on Day Month Year). 